Research Article
(C) 2020 Edet et.al..
P V B I I S H I II G
This is an open access article licensed under the Creative Commons
Attribution-NonCommercial 4.o International License
(https://creativecommons.org/licenses/by-nc/4.0/)

Received: 9 May 2020 / Revised: 23 June 2020 / Accepted: 26 June 2020 / Published: 10 July 2020

\title{
Academic Staff Perception of the Extent of Politicizing Administration of Universities: Implications for National Development
}

\author{
Aniefiok Oswald Edet
}

\section{Michael Ekpenyong Asuquo \\ James Ekpenyong Okon}

\author{
Department of Educational Management, \\ Faculty of Education, University of Calabar, \\ Etagbor, PMB 1115 Calabar 2018, Nigeria
}

DOI: https://doi.org/10.36941/mjss-2020-0039

\begin{abstract}
The aim of this study was to examine academic staff perception of the extent of politicizing administration of universities: Implications for National Development. The study adopted survey research design. The study was guided by two research questions and two research hypotheses. The population of the study was made up of all academic staff in the University of Calabar and Cross River University of Technology, all in Cross River State, Nigeria. Out of the sample size of 430 academic staff used for the study, 250 were males while 180 were females. The instrument for data collection was entitled: "Academic Staff Perception of the Extent of Politicizing Administration of Universities Questionnaire (ASPEPAUQ).” Data collected were analyzed using mean and standard deviation for the research questions. While independent t-test was used to test the two hypotheses formulated for the study. From the result of the study, academic staff members were positive in their perception of the extent of politicizing administration of universities. Male and female academic staff did not differ significantly in their rating of the extent of politicizing administration of universities. It was also found that provision of adequate funds, provision of adequate facilities, proper management of available resources, discouragement of ethnicity and improvement in staff physical/social environment were rated as the vital roles of universities administrators in the administration of universities for national development. It was concluded that due process in practice should be maintained and improved upon by the respective universities administrators to ensure equity and for national development to abound.
\end{abstract}

Keywords: Academic Staff, Perception, Politicizing, Administration, Universities and National Development

\section{Introduction}

The role of education in the development of a country cannot be overemphasized. Education is a tool for individual well being as well as national development. In considering the role of education for national development, Asuquo \& Edet (2019) opined that the inevitable role of education in a country requires for its effective and efficient administration at all levels if it is meant to achieve its goals and objectives. The authors further reiterated that education is the foundation for the growth and development of an economy and that the level of a country's advancement is a function of the standard of education of the country. 
Retrospectively, every human society at any age had its own system of education. What informs this position is that prior to the introduction of modern schooling/formal education (the Western Education in Nigeria), indigenous education was in existence, though it may not have been seen in printed or written form. Evidence abound in literature that as at that time, learners were taught how to respect elders (character and moral training), develop their intellectual and social skills through story telling sessions, riddles, proverbs and poetry. They were taught names of animals, plants as well as how to farm, fish, hunt, carve, knit, cook, weave, sing, dance, drum, wrestle, to mention a few. Learning was pragmatic because the learners learn by doing. All these activities were carried out with available resources to expose the young to various norms, aspirations, values, belief, ethics and culture of the society. Directly or indirectly, these activities were carried out with particular plans and in an organized manner such that people's behavour were manipulated (influenced and controlled) and the available resources of that period effectively utilized to achieve a set goal.

In a bid to achieving the predetermined goal, all activities were done under a given governance. Governance according to Ogbodo (2019) "represents values and rules through which public affairs are managed in a manner that is transparent, participatory, inclusive and responsive. The author further stressed that politics is a precondition for governance and this makes politics necessary for the provision of public education. Thus, politics and administrative processes are pervasive in all groups and are as old as human society. It could be argued therefore that, employment and deployment of human resources as well as provision, utilization, maintenance, replacement and sustainability of available resources to achieve educational goals started along with the existence of human society. In doing all these, administration of available resources must have been done based on the interest of the government and politics of the moment. According to Ekpoh \& Edet (2017) politics has permeated every aspect of human life, the home, religious institutions, public and private organizations as well as educational institutions. The authors emphasized that, politicking has been part and parcel of Nigerian education system and as such we have politics of funding, politics of siting of institutions, politics of provision of facilities and so on.

Politicization is one of the derivatives of politics. Politics per se has different definitions as there are many writers on the concept of politics. For instance, Moore and Roberts (1989) defined politics as a process by which we settle conflicts and distribute scarce resources without resorting to violence. Ebegbulem (2013) viewed politics as the art of influencing, manipulating or confronting groups so as to advance the purpose of some against the opposition of others. From the views of the above scholars, it can be deduced that politics exists in every group or organization whether formal or informal and also within a political party that controls the government policies at the local, state and federal levels. Specifically, the issue of politics in the administration and implementation of university educational policies is inevitable because any form of government in power wants every sector and education sector in particular to function vis-à-vis the needs and interest of the incumbent government. This informs politicization of administration of university education in a typical political and democratic setting or nation.

In this context, politicization of administration of education entails making education a political issue. Politics according to Harold (2010) as cited in Ekpoh and Edet (2017), is a system of who gets what, when and how. Therefore, politicizing administration of universities in this context is limited to some administrative practices carried out in the day-to-day running of the universities. It is common knowledge that administration of education sector in Nigeria has become increasingly political before independence and in recent years. It becomes clear that any political party that controls the government of a country influences every sector of the economy in one way or the other, educational sector inclusive.

For one reason or the other the past and present governments (both regional, military and civilian) influenced educational system significantly. This can also be proved in the introduction of various educational systems, frequent modification of the curriculum and educational policies as well as changes in admission requirements, changes in the names of already existing educational institutions and appointment of office holders without due consideration to areas of specialization. 
The change form 6-3-3-4 to 9-3-4 systems of education in Nigeria also inform political influence on education sector. The former was made so that pupils spend 6 years in primary school, 3 years in junior secondary school, 3 years in senior secondary school and 4 years in the university. The later requires 9 years formal schooling (6 years in primary school and 3 years in junior secondary school), 3 years in senior secondary and 4 years in the university.

With the laudable changes in education sector arising from the dynamic nature of the society and particularly, the interest of government in power, can individual perceive that the best attention has been given to education sector to facilitate national development? If one says that administration of university education in Nigeria is highly politicized or not politicized, it may depend on individual's perspective of what he or she means by politicization of administration of education. Ukpong (2017) observed that politics have a great influence on the formulation and implementation of educational policies, funding of educational programmes, planning and administration of education as well as provision of infrastructural facilities in our educational institutions. To further buttress this observation, Muyiwa (2015) opined that the Nigerian education sector has witnessed unstable programmme implementation. The author stated specifically that dilapidated facilities for effective teaching and learning, poor staffing, monetization of admission process, incessant strike are among the observable problems in Nigerian tertiary education. According to Lenshie (2013) politicization of education has led to the loss of intercontinental cross fertilization of scholarship in the Nigerian universities because of the unfriendly nature of the Nigerian societies to foreign scholars. The author further opined that the usual mixture of scholars from various ethnic, religious and philosophical background in most Nigerian Universities are fast disappearing.

Politicization of administration of university education is informed by the fact that university education does not function in isolation, it operates under the control of a political party that controls the government as well as under the auspices of school administrators that see to the implementation of educational policies and day-to-day running of the universities. A question arises as to whether administration of university education is such that what is in practice is favourably skewed towards or unfavourably skewed from the attainment of national development which is the focus of this study. National Policy on Education (FGN, 2008) stated the objectives of university education as to:

(a) contribute to national development through high level manpower training;

(b) provide accessible and affordable quality learning opportunities in formal and informal education in response to the needs of all Nigerians;

(c) provide high quality career counseling and life-long learning programmes that prepare students with the knowledge and skills for self-reliance and the work of life;

(d) reduce skills shortage through the production of skill manpower relevant to the needs of the labour market.

(e) promote and encourage scholarship, entrepreneurship and community service;

(f) forge and cement national unity; and

(g) promote national and international understanding and interaction.

Administration of education according to Asuquo \& Edet (2019) is the policies implementation function of controlling available material and financial resources as well as directing human efforts to execute formulated major educational policies to achieve stated goals. Specifically, administration of universities in this context is the process of planning for and organizing available material, financial and human resources for proper selection, allocation, budgeting, distribution, judicious utilization, maintenance, replacement as well as ensuring availability and sustainability of both human and material resources to enhance the attainment of the goals of university education.

The Federal Republic of Nigeria (FRN, 2008) stated that administrative services in education include provision of efficient administrative and management control for the maintenance and improvement of the system; quality assurance through regular and continuous supervision of instructional and other educational services and machinery for monitoring and evaluating the implementation of the National Policy on Education Provision. All these are geared towards 
achievement of university educational goals in particular and national development in general.

National development in the context of this work has to do with a nation's growth in all sectors of the economy (educational, political, technological, cultural, social, health, electricity, transportation and communication network, oil and gas, agriculture, good governance) including the all round improvement in the social welfare (food and water supply, clothing, accommodation, electricity, medical care, education opportunities, transportation, low cost and high standards of living, employment opportunities,) of all citizens. In summary, National development is a nation's sustainable growth in all sectors of the economy as well as citizens' wellbeing in all aspects as reflecting in both favourable cost and standard of living. It is common knowledge that national development is a function of the quality of educational services available in a country.

However, Lenshie (2013) opined that the laudable objectives of education have not fully been implemented in the educational system because primordial (long existed or primeval) and patrimonial (heritable nature of) politics have taken the centre stage of the educational sector. It is not uncommon to notice religious discrimination, ethnicity factor, godfatherism, special notes to school administrators from prominent politicians, practice of dichotomy between indigene and nonindigene, employment of mediocre, inadequate budgetary allocation to education, misappropriation of fund, existent of cabal (a group of staff within educational institution who are involved in secret plans to take over political power), regionalism and so on in the educational system. One begins to wonder if these practices are sure ways to national development or otherwise.

\section{Literature Review}

Lodesso \& Warito (2016) investigated perceptions of academic staff: does internal quality management contribute to the improvement of teaching-learning process? The case of Ethiopian Higher Education. The result of the findings showed that academic staff of the universities in Ethiopian perceived the internal quality management practice as poor. Also, Adetunji \& Ogunleye (2015) investigated the effect of government policies on university administrators: A review of Nigeria. The result of the study indicated that government policies and practices on the implementation of decisions influenced universities administrators' responses to the development of the university system. Afolabi, Ekundayo \& Ogbiye (2020) carried out a study on politics and university administration in Nigeria and found that politics had not impacted much on administration of universities in Nigeria.

Aburi (2004) conducted a study on academic staff perceptions of and the actual working conditions in the University of Nairobi and their likely influence on brain drain. The population of the study was made up all academic staff in the University of Nairobi. With the sample size of 109 academic staff, the study found that academic staff in the University of Nairobi was not satisfied with all aspects of their working conditions. Working conditions was perceived by majority to be very poor. Idogho (2006) in a study on academic staff perception of organizational climate in universities in Edo State, Nigeria, discovered that academic staff in universities in Edo State perceived the organizational climate of their institutions as favourable. Again, the result of the study also indicated that academic staff did not differ in their perception of organizational climate in their institutions in terms of sex, age and status.

Mamedu \& Ahiakwo (2016) examined academic staff perception of quality of working-life and university goal attainment in the south - south geo-political zone of Nigeria. Results of the study showed a state of satisfactory quality of work -life for the staff as well as a state of unfavourable university goal attainment. In addition, insignificant relationship between quality of work -life and university goal attainment was also found as another result of the study. Ahmed, ,Baloch \& Ghani (2015) in a study on the impact of organizational politics on the productivity of employees: An empirical investigation from Pakistan with a Sample size of 280 respondents working in different organizations across Pakistan at different management levels found no significant relationship between politicking in organization and productivity of employees in lower and higher management. 
The present study on academic staff perception of the extent of politicizing administration of universities: Implications for national development is different from other studies reviewed. Due to its peculiarity, its thus intends to fill the gap identified in literature.

\section{Statement of the Problem}

Education at any period and level is meant to expose every individual to various norms, values, aspirations, beliefs, culture/tradition, social responsibilities, occupational orientation, politics of a society as well as enhancing sound and effective citizens who will subsequently contribute their quotas towards national development. Evidence also abound in literature that the level of a nation's science and technology, sustainable development and national development in particular dependent greatly on quality of her education. This position is in line with the fact that there is no country that rises above the level of her education. Specifically, university education, the highest level of education in the world is meant to contribute to national development through high level manpower training, reduce skills shortage through the production of skill manpower relevant to the needs of the labour market, promote and encourage scholarship, entrepreneurship and community service, forge and cement national unity, promote national and international understanding and interaction among others.

In spite of the aforementioned objectives of the university education, incident of poor funding which is the major cause of other problems such as inadequate teaching and learning facilities, dilapidated facilities, poor staffing, frequently strike action by academic staff resulting from lectures' dissatisfaction and sub-standard physical work environment. Problems in the university system also manifest in appointment of staff on the basis of godfatherism, indigene, religious affiliation and political influence as opposed to emphasis on interview to select and appoint the best manpower for the system. With these chronic problems in the system, the researcher is left to wonder if Nigeria as an independent nation is moving towards attainment of national development. Thus, this study investigated academic staff perception of the extent of politicizing administration of universities: Implications for national development.

\section{Purpose of the Study}

This study was carried out to find out academic staff perception of the extent of politicizing administration of universities.

Specifically, this study aimed at:

1. Finding out academic staff perception of the extent of politicizing administration of universities.

2. Identifying the roles of stakeholders in the administration of universities for national development

\section{Research Questions}

1. To what extent is administration politicized in the universities?

2. What are the roles of stakeholders in the administration of universities for national development?

\section{Research Hypotheses}

1. There is no significant difference between male and female academic staff in extent to which they perceived politicization of administration in the universities.

2. There is no significant difference in the mean response of male and female academic staff in the roles of stakeholders in the administration of universities for national development. 


\section{Methodology}

A survey research design was adopted for this study. Isangedighi, Joshua, Asim \& Ekuri (2004) opined that a survey research design is concern with data collection and using them objectively to describe current phenomena. This design was considered appropriate because the present study was directed towards determining the nature of a situation as at the time the study was conducted. The population of this study was made up of all academic staff in the University of Calabar and Cross River University of Technology, all in Cross River State, Nigeria.

At first instant, stratified random sampling technique was adopted to select the sample of 430 academic staff ( 250 males and 180 were females) for the study. Stratified random sampling technique was considered appropriate in this study because it addresses heterogeneity in the population. To ensure sample that is representative of the population being studied, the population of the academic staff in the public Universities in Cross River State was first stratified by Faculties, Institutes, followed by Departments and then by males and females academic staff. At the homogeneous sub-sets (males and females) the sample of the study was randomly selected.

The instrument for data collection was developed by the researchers and was titled "Academic Staff Perception of the Extent of Politicizing Administration of Universities Questionnaire (ASPEPAUQ)." Three experts in Educational Management handled the content validity of the instrument while another three experts in Test and Measurement handled the face validity. The experts consulted for the validation of the instrument were in the Faculty of Education, University of Calabar, Calabar.

The instrument was divided into three (3) sections, A, B and C. Section A obtained demographic data, that is respondents' (academic staff) personal data. Section B and C were structured questionnaire with response options of Very High Extent (VHE), High Extent (HE), Low Extent (LE), Very Low Extent (VLE) and Strongly Agree (SA), Agree (A), Disagree (D), Strongly Disagree (SD) respectively. VHE and SA, HE and A, LE and D and VLE and SD were each assigned nominal values of $4,3,2$, and 1 respectively. The decision point of 2.50 arising from the average of the nominal values was used. With this decision point, any item on the questionnaire with a mean score of 2.50 and above was regarded as indicating Very High Extent (VHE), High Extent and Agreed opinion while item with the mean score of less than 2.50 indicated Low Extent, Very Low Extent and Disagreed opinion by the respondents. With the help of research assistants, the researchers administered copies of questionnaire to the respondents. The data collected were analyzed using mean and standard deviation for the research questions while independent t-test was used to test the two hypotheses formulated for the study.

\section{Results}

\subsection{Research question 1}

To what extent is administration politicized in the universities?

Table 1: Mean rating with standard deviation of academic staff perception of the extent to which administration is politicized in the universities.

\begin{tabular}{lccc}
\hline \hline S/N Administrative practices & $\bar{X}$ & SD & Decision \\
\hline 1. Allocation of courses to the lecturers & 2.82 & 1.368 & HE \\
2. Methods of offer of appointment in recent time & 3.82 & 1.633 & VHE \\
3. Appointment of principal officers within the university & 2.89 & 1.200 & HE \\
4. Appointment of membership into various committees within university & 3.77 & 1.678 & VHE \\
5. Appointment of academic advisers & 2.90 & 1.524 & HE \\
6. Office of the HODs & 2.52 & 1.007 & HE \\
\hline
\end{tabular}




\begin{tabular}{lccc}
\hline \hline S/N Administrative practices & $\bar{X}$ & SD & Decision \\
\hline 7. Deanship position & 2.62 & $\mathbf{1 . 2 0 0}$ & HE \\
8. Award of research grants & 2.64 & $\mathbf{1 . 2 0 9}$ & HE \\
9. Award of Honorary Degrees by Universities to political office holders & 2.73 & 1.300 & HE \\
10. Academic staff promotion criteria & 2.86 & 1.443 & HE \\
Total mean & $\mathbf{3 . 0 2}$ & $\mathbf{1 . 6 2 1}$ & \\
\hline
\end{tabular}

Note: Mean scores of 2.50 and above is significant. While mean scores below 2.50 is not significant.

The data in table 1 indicate that, academic staff perception of the extent of politicizing administration of universities with respect to the above 10 items is high. Their position is upheld because the mean scores of their responses are all significant since all the scores are more than the cut-off point of 2.50. Methods of offer of appointment in recent time (3.82) as well as appointment of membership into various committees within universities (3.77) were perceived by academic staff as being very highly politicized in recent time in the universities studied.

\subsection{Research question 2}

What are the roles of stakeholders in the administration of universities for national development?

Table 2: Mean rating with standard deviation of academic staff on the roles of stakeholders in the administration of universities for national development?

\begin{tabular}{lccc}
\hline \hline S/N The roles of stakeholders & $\bar{X}$ & SD & Decision \\
\hline 1. Provision of adequate funds & 3.88 & 1.567 & Agree \\
2. Provision of adequate facilities & 3.67 & 1.342 & Agree \\
3. Maintenance of facilities & 2.83 & 1.645 & Agree \\
4. Employment based on merit & 2.51 & 1.144 & Agree \\
5. Improvement in staff welfare & 2.53 & 1.101 & Agree \\
6. Improvement in staff capacity building & 2.86 & 1.223 & Agree \\
7. Encouragement of credibility & 2.54 & 1.557 & Agree \\
8. Avoidance of ethnicity & 2.78 & 1.154 & Agree \\
9. Improvement in staff physical/ social environment & 3.00 & 1.393 & Agree \\
10. Discouragement of ethnicity & 3.12 & 1.300 & Agree \\
11. Proper management of available resources & 3.14 & 1.432 & Agree \\
Total Mean Score and SD & 3.88 & $\mathbf{1 . 5 4 3}$ & \\
\hline
\end{tabular}

Note: Mean scores of 2.50 and above is significant. While mean scores below 2.50 is not significant.

Table 2 shows that the respondents of the study agreed that all the 11 items were the roles of the stakeholders in the administration of universities for national development as the mean responses were all greater than the cut-off point of 2.50. The first two items (provision of adequate funds and provision of adequate facilities) with 3.88 and 3.67 means respectively were the most important roles of the stakeholders in the administration of universities for national development

\subsection{Hypothesis 1}

Table 3: Independent t-test analysis of the mean difference of males and females academic staff responses of the extent to which administration is politicized in the universities.

\begin{tabular}{lcccccc}
\hline Academic staff & $\mathrm{N}$ & Mean & Standard Deviation & Standard error Mean & t-test & Sig (2-tailed) \\
\hline Male & 250 & 3.40 & 1.35 & .230 & \multirow{2}{*}{0.690} & \multirow{2}{*}{0.690} \\
Female & 180 & 3.35 & 1.25 & .255 & & \\
\hline
\end{tabular}

Not Significant at $\mathrm{p}<.05 \quad \mathrm{t}(428)=1.965$ 
The result of the analysis presented in Table 3 shows that the calculated t-value of .280 is less than the critical t-value of 1.965 at 0.05 level of significance and 428 degrees of freedom. The analysis also shows that the mean score of male academic staff is 3.40 , which is not significantly different from the 3.35 mean score of their female counterparts. With this result therefore, the null hypothesis is retained. This means that, the perception of male and female academic staff to the extent in which administration is politicized within the universities was not differ with respect to their sex.

\subsection{Hypothesis 2}

Table 4: Independent t-test analysis of the mean difference of male and female academic staff of the roles of stakeholders in the administration of universities for national development.

\begin{tabular}{lcccccc}
\hline Academic staff & $\mathrm{N}$ & Mean & Standard Deviation & Standard error Mean & t-test & Sig (2-tailed) \\
\hline Male & 250 & 3.31 & 1.88 & .270 & .244 & \multirow{2}{*}{0.690} \\
Female & 180 & 3.20 & 1.54 & .250 & .244 \\
\hline
\end{tabular}

Not Significant at $\mathrm{p}<.05 \quad \mathrm{t}(428)=1.965$

The result of the analysis presented in Table 4 shows that the calculated t-value of .244 is less than the critical t-value of 1.965 at 0.05 level of significance and 428 degrees of freedom. The analysis also shows that the mean score (3.31) of male academic staff is not significantly different from the 3.20 mean score of their female counterparts. With this result therefore, the null hypothesis is retained. This means that there was no significant difference in the mean response of male and female academic staff with respect to the roles of stakeholders in the administration of universities for national development. Both males and females academic staff had the same opinion with regards to the roles of the stakeholders in the administration of universities for national development.

\section{Discussion of Findings}

From the first research question, it was found that administrative processes in terms of allocation of courses to the lecturers, methods of offer of appointment in recent time, appointment of principal officers within the university, appointment of membership into various committees within university, appointment of academic advisers, office of the HODs, Deanship position, award of research grants, award of Honorary Degrees by Universities to political office holders and academic staff promotion criteria are highly politicized within the universities.

The above finding is in supports of Lenshie (2013) who opined that the laudable objectives of education have not fully been implemented in the educational system because primordial and patrimonial politics have taken the centre stage of the educational sector. The result of this finding is also in collaboration with Lodesso \& Warito (2016) whose study indicated that academic staff of the universities in Ethiopian perceived the internal quality management practice as poor. The explanation of this finding is that cabal (small group of people with secret plans to get political power), ethnicity, religion, existence of primordial and patrimonial practices assume dominance in determining who get "what", "when" and "how" in the administration of universities. If the internal administrative practices are to the detriment of the universities or otherwise, what then is the position of national development?

However, the result of this study is not in line with the finding of Afolabi, Ekundayo \& Ogbiye (2020) who investigated "Politics and university administration in Nigeria" and found that politics had not impacted much on administration of universities in Nigeria. Also, the findings of the present study is not in support of Idogho (2006) whose study indicated that, academic staff in universities in Edo State perceived the organizational climate of their institutions as favourable.

Table 2 shows the roles of the stakeholders in the administration of universities for national development. Respondents agreed on the roles identified in this work as what stakeholders must do 
to facilitate administration of universities for national development. This is evident in the mean scores which are above the cut-off point of 2.50. This result indicates that provision of adequate funds, provision of adequate facilities, maintenance of facilities, employment based on merit, improvement in staff welfare, improvement in staff capacity building, promotion of credibility, improvement in staff physical/social environment, discouragement of ethnicity, proper management of available resources are the roles of the stakeholders in the administration of education for national development.

Academic staff members were positive in their perception of provision of adequate funds as the major role of the stakeholders in the administration of universities for national development. This means that administration of universities for national development is contingent upon provision of adequate funds. Adequate funds is crucial because it facilitates availability of school facilities, professional training of academic staff in the universities who subsequently sustain and contribute to generation and dissemination knowledge, skills and competencies in students who will contribute their quotas towards national development. Effective administration of universities requires adequate and judicious funding. This is because adequate funding remains a major instrument in the development, improvement, sustenance and expansion of the university system. It is at the core of effective administration of university for national development. Other challenges in the universities can be reasonably reduced if not totally solved with effective and efficient funding. This finding is in line with Eberechi, Chindah \& Ereh (2016) who stated that adequate funding enhances availability of school facilities, availability of infrastructure, teachers' incentives/welfare, quality standard, quality teaching as well as good result.

The finding of this study also indicates that males and females academic staff do not differ significantly in their mean responses of the extent to which administration is politicized in the universities as well as in their mean responses of the roles of stakeholders in the administration of universities for national development. This result is in consonant with Idogho (2006) whose study indicated that academic staff did not differ in their perception of organizational climate in their institutions in terms of sex, age and status. This means that gender is not a significant factor in determining academic staff opinion with respect to the extent to which administration is politicized in the universities and the roles of stakeholders in the administration of universities for national development. This result further indicates that males and females academic staff members are alike in many respects because in addition to doing the same teaching, research and community services, they are under the same university administration. This makes them to perceive university administration and its politics as well as the roles of stakeholders in the administration of universities for national development in the same way.

\section{Implications for National Development}

The role of administration in the universities cannot be overemphasized since it is the doing function of administrators. Researchers acknowledge the fact that administration involves getting things done through people and effective mobilization of available human, material and financial resources (Asuquo \& Edet, 2019). The authors stressed that with administration as a process, institutional administrators initiate ideas, direct institutional programmes and activities, control, supervise and monitor all resources (human, financial and materials) and carefully use them to achieve organizational goals. As stated in FGN (2008), one of the goals of university education is to contribute to national development through high level manpower training. Therefore, effective administration in the day-today running of the universities is a sure way to university system goal attainment.

However, the politics of who gets what, when and how playing out at the expense of due process in the universities will have a serious adverse implications for national development if not nip in the bud. The implications will not only result in the employment of mediocrities, production of low level manpower, poor quality teaching/learning opportunities and discouragement of scholarship but also in worsening and bringing down national understanding and interaction as well as increasing 
religious discrimination, godfatherism, indigene and non-indigene dichotomy, existence of cabals, regionalism to mention a few. For national development to be improved, administration of universities by the stakeholders should be devoid of any form of politics that negate due process in the administrative matters affecting the smooth operation of all the affairs in the universities.

\section{Conclusion}

Administration is inevitable in the achievement of educational goals. These goals subsequently enhance national development. This points to the fact that, no nation can grow above the quality of her education. It is important to note that national development which cuts across a nation's growth and development in all sectors of the economy and all aspects of citizens' wellbeing depends to a very great extent on the effective administration of university system. The deplorable level of education will abound if its administration is not free from or devoid of political undertones. In spite of the inadequate fund from the government, due process in practice should be maintained and improved upon by the respective universities administrators. By so doing, irrespective of individuals' ethnic group, religious affiliation and interest, equity will abound and national development assured.

\section{Recommendations}

Based on the findings of this study, the following recommendation were made

1. Administration of universities should be based on due process devoid of political influence whatsoever.

2. Educational stakeholders in the university system should improve upon and sustain their roles as identified in this work so as to enhance national development.

\section{References}

Adetunji, A. T. \& Ogunleye, K. A. (2015). The effect of government policies on university administrators: A review of Nigeria. Ge-internatioal Journal of Management Research, 3(5),55-69 https://www.researchgate.net /publication/308962272-the-effectgovernment-policies on university administrators a review of Nigeria

Aburi, S. N. (2004), Academic Staff Perceptions of and the actual working conditions in the University of Nairobi and their likely influence on brain drain. Unpublished Master of Art Degree in Development Studies, Institute for Development Studies, University of Nairobi. https://pdfs.semanticscholar.org/b5f7 /fd 918896fia4f5cce2f8dda3f28496fa54c.pdf

Afolabi, C. Y., Ekundayo, H. T., \& Ogbiye, C. A. (2020). Politics and University Administration in Nigeria, British Journal of Education, 8(5), 15-25. https://www.eajournals.org/journals/british-journal-of-education-bje/vol8-issue-5-may- 2020/politics-and-university-administration-in-nigeria/

Ahmed, M. , Baloch, A. \& Ghani, H. (2015) .The impact of organizational politics on the productivity of employees: An empirical investigation from Pakistan. Gomal University Journal of Research, 31(2). https://www.researchgate.net/publication/330873251_the_impact_of_organizational_pitics_on_the_productivi ty_of_employees_an_empirical_investigation_from_pakistan

Asuquo, M. E. \& Edet, A. O. (2019). Administration of basic education for good governance in Nigeria. Problem and prospects. Prestige Journal of Counselling Psychology. 2(1), 74 -84.

Ebegbulem, J. (2010). Government and politics of the modern States: Enlarged edition. Kings View Publishing House.

Eberechi, N. I., hindah, G. C. \& Ereh, C. E. (2016). Strategies in funding primary education for sustainable development. In N. M. Abraham, D. O. Durosaro, Y. I. Wunti, G. G. Kpee, F. T. Bua, \& O. E. Okpa.(Eds.). Changes and Innovations in Financing Education for Sustainable National Development (pp.135-142). University of Port Harcourt Press Limited.

Ekpoh, U. I. \& Edet, A. O. (2017). Politics of programme accreditation practices in Nigerian Universities: Implications for quality assurance. Journal of Educational and Social Research, 7(2), 73-79.

Federal Republic of Nigeria (FRN) (2008). National policy on education. Lagos: NERDC Press. 
Idogho, P. O. (2006). Academic staff perception of the organizational climate in Universities in Edo State, Nigeria. J. Soc. Sci., 13 (1), 71-18. http://www.krepublishers.com/o2-Journals/JSS/JSS-13-o-ooo-ooo-20o6-Web/JSS-13-1-oo1o82-2006-Abst-Text/JSS-13-1-071-078-2006-402-Idogho-P-O/JSS-13-1-071-078-2006-402-Idogho-P-O-Text.pdf

Isangedighi, A. J., Joshua, M. T. Asim, A. E. \& Ekuri, E. E. (2004). Fundamentals of research and statistics in education and social sciences. University of Calabar Press.

Lodesso, S. L. \& Warito, F. A. (2016). Perceptions of academic staff: Does internal quality management contribute to the improvement of teaching-learning process? The case of Ethiopian higher education. IOSR Journal Of Humanities And Social Science (IOSR-JHSS), 21 (2), 39-45. http://www.iosrjournals.org/iosrjhss/papers/Vol.\%2021\%2oIssue2/Version-4/Go21243945.pdf

Lenshie, N. E. (2013). Politicization of education in Nigeria: Implication for national transformation. Global Journal of Human Social Science Political Science, 13(5), 2333.

Mamedu, O. P. \& Ahiakwo, M.J. (2016). Academic staff perception of quality of working-life and university goal attainment in the south - south geo-political zone of Nigeria. Journal of Good Governance and Sustainable Development in Africa (JGGSDA), 3(3):1-19. http://rcmss.com/2017/JGGSDA/Academic-Staff-Perception-ifQuality- of-Working-Life-and-University-Goal-Attainment-in-the-South-GCo-South-Geo Political\%2oZoneof-Nigeria.pdf

Muyiwa, S. A. (2015). Education and politics: Its implication for national transformation in Nigeria. Public Policy and Administration Research, 5(8), 40-45.

Moore, J. A. \& Robert, M. (1989). Government and politics in America. Macmillan Publishing Company.

Ogbodo, C. M. (2019). Politicizing Education in Nigeria: Implications for National Development. A Lead paper presented at the $8^{\text {th }}$ Annual National Conference on Education Organized by Faculty of Education, University of Uyo, Uyo, Akwa Ibom State on the theme: Politicizing education in Nigeria: Implications for national development held on $10^{\text {th }}-13^{\text {th }}$ September, 2019 at Onyema Ugochukwu Auditorium, Town Campus.

Ukpong, N. N. (2017). Politics and educational policies implementation: Focus on Universal Basic Education in Akwa Ibom State, Nigeria. European British Journal of Education, 5 (13), 99-108. 